\title{
LOAD-CAPACITY PREDICTION FOR THE CARBON- OR GLASS-FIBRE-REINFORCED PLASTIC PART OF A WRAPPED PIN JOINT
}

\author{
NAPOVED NOSILNOSTI PLASTIČNIH DELOV ZATIČNEGA \\ SPOJA, OJAČANEGA Z OGLJIKOVIMI ALI STEKLASTIMI \\ VLAKNI
}

\author{
Jan Krystek, Radek Kottner \\ University of West Bohemia in Pilsen, NTIS - New Technologies for the Information Society, Technická 8, 30614 Plzeň, Czech Republic \\ krystek@kme.zcu.cz, kottner@kme.zcu.cz \\ Prejem rokopisa - received: 2014-11-28; sprejem za objavo - accepted for publication: 2015-01-09
}

doi:10.17222/mit.2014.289

\begin{abstract}
A joint using a metal pin is one possibility of how to achieve a removable joint of composites. The load capacity of a wrapped pin joint depends on many parameters, especially on the types of fibres and resin, and geometric properties of the joint. The composite part of a wrapped pin joint is exposed to a combination of the tension in the longitudinal direction and local compression in the transverse direction. The values of the compressive stress in the transverse direction can exceed several times the uniaxial compressive strength. In this work, CFRP (carbon-fibre-reinforced plastic) and GFRP (glass-fibre-reinforced plastic) parts of wrapped pin joints were tested. Experimental specimens with different geometries were exposed to a quasi-static loading. A Zwick/Roell Z050 testing machine was used for the tensile tests. Moreover, the load capacities of the carbon or glass composite parts were determined using a finite-element analysis. A new measure based on the LaRC04 criterion was proposed for the prediction of the load capacity. The numerical and experimental results were compared.

Keywords: composite, finite-element method, load capacity, loop criterion, wrapped pin joint
\end{abstract}

Spoji z uporabo kovinskega zatiča so ena od možnosti, kako doseči odstranljivo kompozitno povezavo. Nosilnost zavite stične povezave je odvisna od mnogih parametrov, posebno od vrste vlaken in smole ter geometrijskih lastnosti povezave. Kompozitni del zavite zatične povezave je izpostavljen kombinaciji napetosti v vzdolžni smeri in lokalnim tlakom v prečni smeri. Vrednosti tlačnih napetosti v prečni smeri lahko večkrat presežejo enoosno tlačno trdnost. V tem delu so bili preizkušeni zaviti zatični spoji z deli iz CFRP (plastika, ojačana z ogljikovimi vlakni) in GFRP (plastika, ojačana s steklenimi vlakni). Preizkusni vzorci z različno geometrijo so bili izpostavljeni kvazistatični obremenitvi. Za natezne preizkuse je bila uporabljena naprava Zwick/Roell Z050. Poleg tega je bila nosilnost kompozitnih delov z ogljikovimi ali steklastimi vlakni določena $\mathrm{z}$ uporabo analize končnih elementov. Novo merilo, ki temelji na merilu LaRC04, je bilo predlagano za napovedovanje nosilnosti. Primerjani so numerični in eksperimentalni rezultati.

Ključne besede: kompozit, metoda končnih elementov, nosilnost, merilo zanke, zavit spoj s kovinskim zatičem

\section{INTRODUCTION}

Joints are often the critical parts of constructions. This work focuses on wrapped pin joints. The main principle of manufacturing the wrapped pin joints is to place the wrapping fibres of a composite directly around the metal pin, precisely following its shape. It allows creating a joint without any cutting fibres, which results in a high load capacity of the joint. ${ }^{1}$

The curved composite part (loop - Figure 1) of a wrapped pin joint is exposed to a combination of the tension in the longitudinal direction (1 in Figure 2) and the compression in the transverse direction (3 in Figure 2) during a tensile loading of the joint. The tensile and compressive stresses in the loop reach significantly high values compared with the ultimate strengths in the principal material directions. No standard criterion for a correct failure prediction of the loop was found. ${ }^{1,2}$ Therefore, the $\mathrm{LaRC} 4^{3}$ criterion was adjusted ${ }^{2}$ so that the failure of the loop was also described. In the case of freely fastened (FF) loops, a matrix failure reduces the loop's load capacity (if a matrix failure occurs). The matrix failure results in a separation of the wrapping's cross-section. In the case of tightly fastened (TF) loops, a matrix failure does not influence the loop's load capacity. The difference between the fastenings is explained in Figure 3.

However, the parameters of the adjusted LaRC04 criterion $^{2}$ depend on the types of the composite and fastening. ${ }^{4}$ Therefore, a new criterion was proposed in this work.

Experimental and numerical investigations of the loop's load capacity for a wrapped pin joint and a comparison of the experimental and numerical results were the aims of this work. Two types of composite fibres were used in these analyses.

\section{EXPERIMENTS}

Experimental specimens (unidirectional composite loops - Figure 1) were manufactured using the fila- 


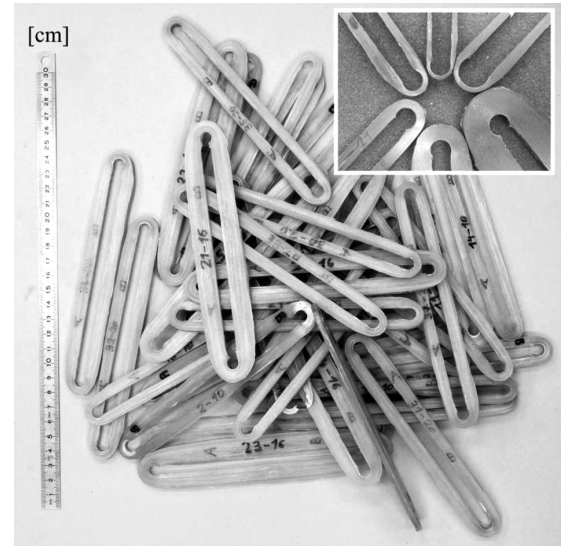

Figure 1: Loops with different geometries

Slika 1: Zanke z različno geometrijo

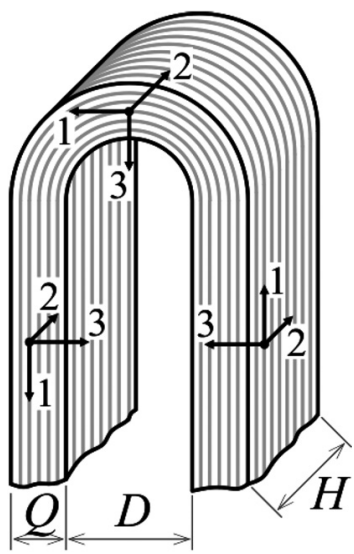

Figure 2: Geometric parameters of the loop and the principal material directions

Slika 2: Geometrijski parametri zanke in osnovne smeri materiala

ment-winding technology. Carbon or glass fibres and epoxy resin were used. Mechanical properties of the composites are presented in Table 1.

The joints were exposed to a tensile quasi-static loading (the loading speed was $0.5 \mathrm{~mm} / \mathrm{min}$ ) at a temperature of $+22{ }^{\circ} \mathrm{C}$. A Zwick/Roell Z050 testing machine was used. The description of geometric parameters is obvious from Figure 2: the diameter of pins $(D)$ is $8 \mathrm{~mm}$, the thickness of the loops $(H)$ is $3 \mathrm{~mm}$ and the width $(Q)$ is 1-9 $\mathrm{mm}$. FF and TF loops were tested.

Table 1: Mechanical properties of the tested composites

Tabela 1: Mehanske lastnosti preizkušenih kompozitov

\begin{tabular}{|c|c|c|c|c|c|c|}
\hline \multicolumn{7}{|c|}{ carbon fibres + epoxy $\left(\mathrm{LG} 120+\right.$ EM100) $\quad\left(V_{\mathrm{f}}=0.65\right)$} \\
\hline $\begin{array}{c}E_{1} \\
(\mathrm{GPa}) \\
118.9\end{array}$ & $\begin{array}{c}E_{2} \\
(\mathrm{GPa}) \\
4.7\end{array}$ & $\begin{array}{c}G_{12} \\
(\mathrm{GPa}) \\
2.0\end{array}$ & $\begin{array}{c}v_{12} \\
- \\
0.35 \\
\end{array}$ & $\begin{array}{c}X^{\mathrm{T}} \\
(\mathrm{MPa}) \\
3264\end{array}$ & $\begin{array}{c}Y^{\mathrm{C}} \\
(\mathrm{MPa}) \\
92 \\
\end{array}$ & $\begin{array}{c}S^{\mathrm{L}} \\
(\mathrm{MPa}) \\
48\end{array}$ \\
\hline \multicolumn{7}{|c|}{ glass fibres + epoxy $(\mathrm{LH} 298+\mathrm{H} 512) \quad\left(V_{\mathrm{f}}=0.73\right)$} \\
\hline $\begin{array}{c}E_{1} \\
(\mathrm{GPa}) \\
52.6\end{array}$ & $\begin{array}{c}E_{2} \\
(\mathrm{GPa}) \\
8.6\end{array}$ & $\begin{array}{c}G_{12} \\
(\mathrm{GPa}) \\
4.7\end{array}$ & $\begin{array}{c}v_{12} \\
-\overline{30} \\
0 .\end{array}$ & $\begin{array}{c}X^{\mathrm{T}} \\
(\mathrm{MPa}) \\
2000\end{array}$ & $\begin{array}{c}Y^{\mathrm{C}} \\
(\mathrm{MPa}) \\
50\end{array}$ & $\begin{array}{c}S^{\mathrm{L}} \\
(\mathrm{MPa}) \\
48\end{array}$ \\
\hline
\end{tabular}

A comparison of force-displacement curves of the specimens with the same geometry $(Q=5.5 \mathrm{~mm})$ and of
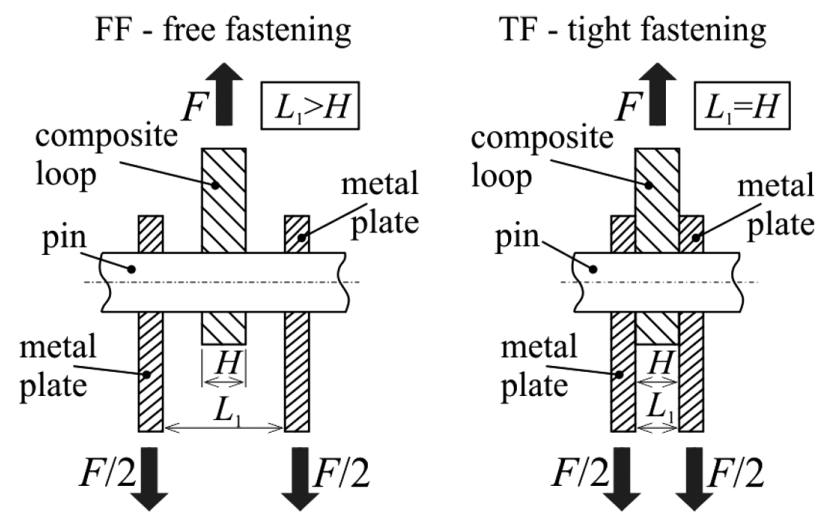

Figure 3: Types of loop fastening Slika 3: Vrsta pritrditve zanke

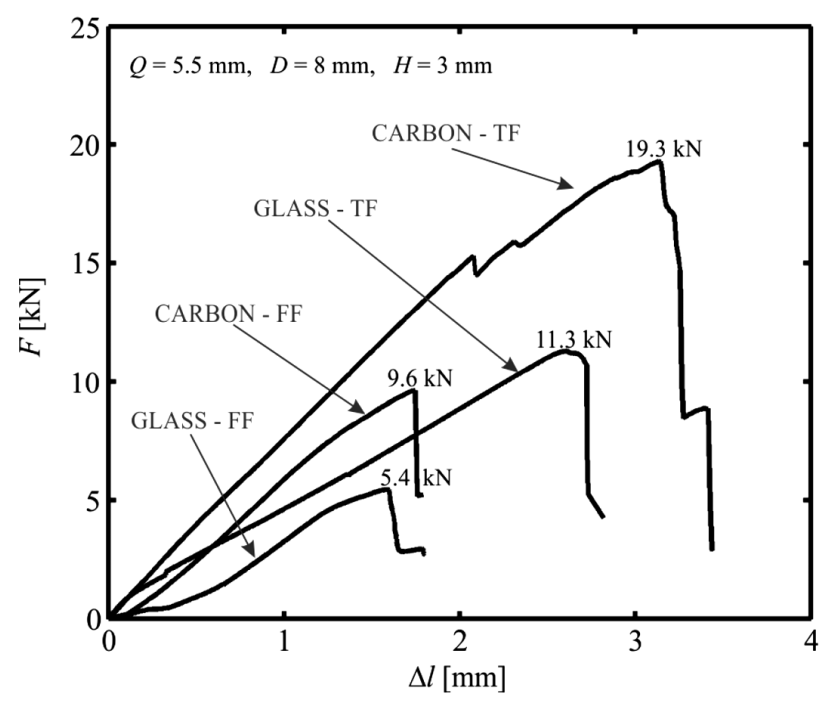

Figure 4: Comparison of force-displacement curves Slika 4: Primerjava krivulj sila - raztezek

different materials and types of fastening is shown in Figure 4. Experimental dependencies of the load capacity $F_{\max }$ on the width $Q$ are presented in Figure 5 (TF

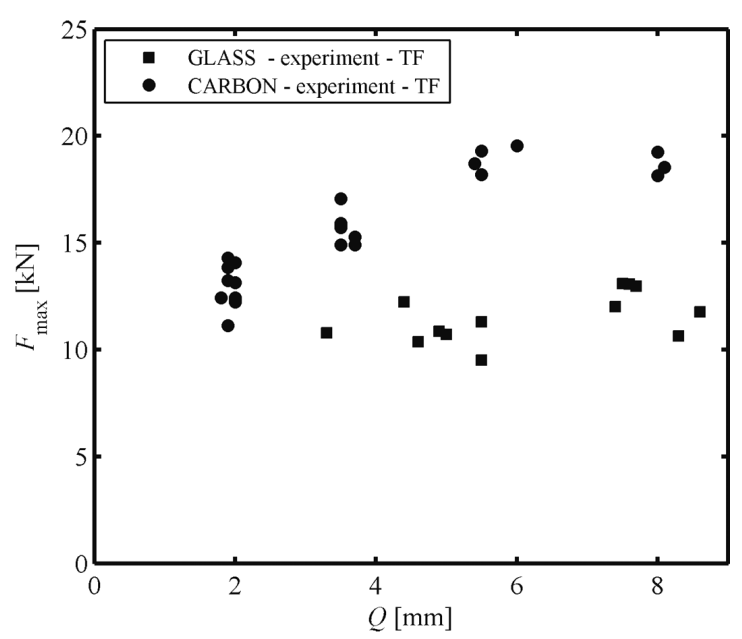

Figure 5: Load capacity of TF loops - experiment Slika 5: Nosilnost TF-zank - preizkus 


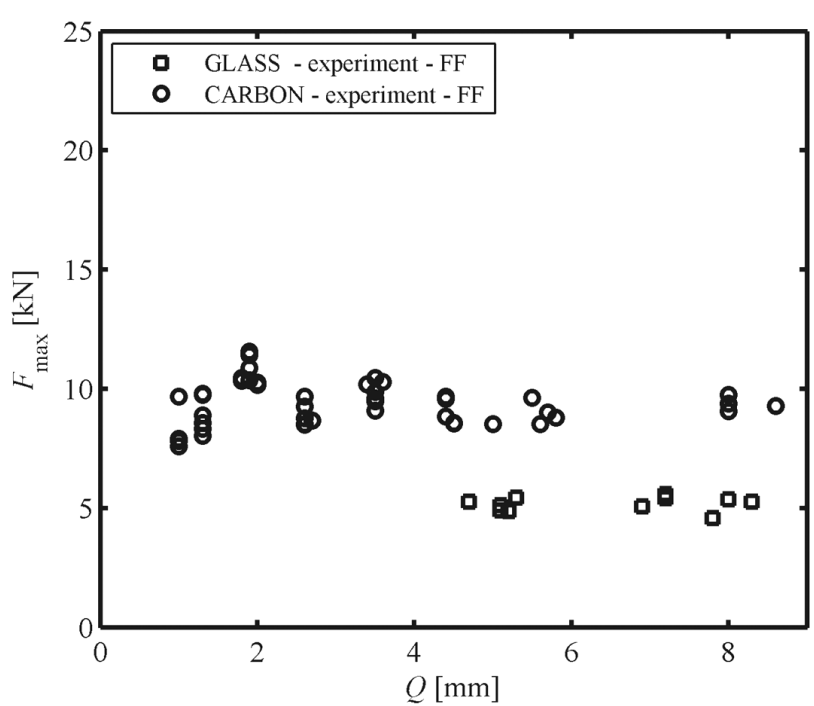

Figure 6: Load capacity of FF loops - experiment Slika 6: Nosilnost FF-zank - preizkus
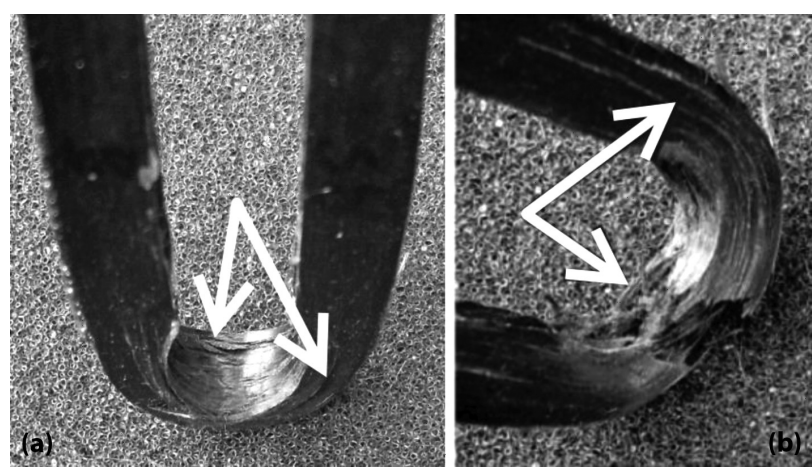

Figure 7: Failures of a: a) FF loop and b) TF loop Slika 7: Porušitev: a) FF-zanke in b) TF-zanke

loops) and Figure 6 (FF loops). The diameter $D$ was $8 \mathrm{~mm}$ and the thickness $H$ was $3 \mathrm{~mm}$. Typical failures of the FF and TF loops are presented in Figure 7.

\subsection{Numerical simulations}

The finite-element system MSC. Marc was used for the numerical simulation. Linear hexahedral elements with eight nodes (SOLID elements) were used in a parametrically created model. Due to the symmetry of the loop, only one eighth of the loop was modelled. The properties of transversely isotropic material were assigned to the elements considering the orientations of the fibres. The loading was controlled with a displacement of the rigid surface, which simulated the pin (Figure 8). The friction was neglected.

The loop criterion was proposed in this work. It is based on the LaRC04 criterion $^{3}$ and respects the specific combination of the stresses in a loop. ${ }^{4}$ The failure index in the case of the fibre-failure mode $\left(\sigma_{1}>0\right)$ of the loop criterion is:

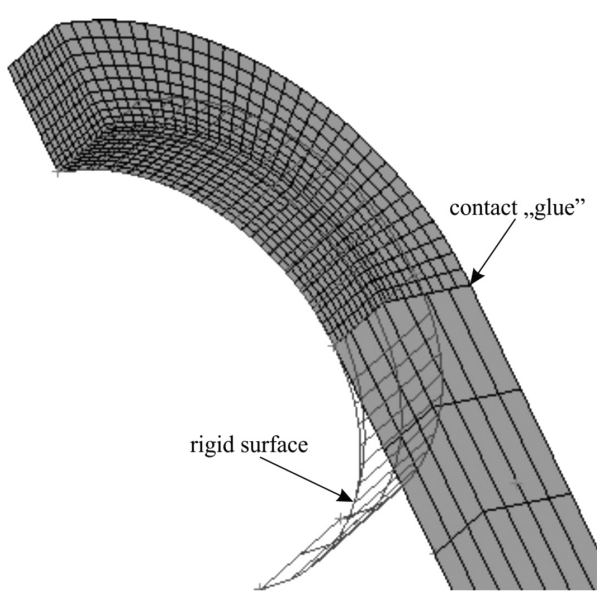

Figure 8: Mesh of the finite-element model Slika 8: Mreža modela končnih elementov

$$
F I_{\mathrm{F}}=\frac{\sigma_{1}}{\frac{X^{\mathrm{T}}-X^{\mathrm{T}} \cdot P_{\mathrm{f}}}{Y^{\mathrm{C}}+X^{\mathrm{T}} \cdot P_{\mathrm{m}}} \cdot \sigma_{3} \cdot P_{\mathrm{f}}+X^{\mathrm{T}}} \leq 1
$$

where $P_{\mathrm{f}}$ and $P_{\mathrm{m}}$ are the criterion parameters (the loop parameters), $X^{\mathrm{T}}$ is the tensile strength in the longitudinal direction and $Y^{\mathrm{C}}$ is the compressive strength in the transverse direction. The failure index in the case of the matrix-failure mode $\left(\sigma_{3}<0, \sigma_{1} \geq 0\right)$ of the loop criterion is:

$$
F I_{\mathrm{M}}=\left(\frac{\tau^{\mathrm{T}}}{S^{\mathrm{T}}-\eta^{\mathrm{T}} \sigma_{\mathrm{n}}+\sigma_{1} P_{\mathrm{m}}}\right)^{2}+\left(\frac{\tau^{\mathrm{L}}}{S^{\mathrm{L}}-\eta^{\mathrm{L}} \sigma_{\mathrm{n}}+\sigma_{1} P_{\mathrm{m}}}\right)^{2} \leq 1
$$

where $\tau^{\mathrm{T}}$ and $\tau^{\mathrm{L}}$ are the stresses in the plain of the failure ( $T$ - transverse direction, $L-$ longitudinal direction), $\eta^{\mathrm{T}}$ and $\eta^{\mathrm{L}}$ are the coefficients of friction, $S^{\mathrm{T}}$ is the transverse shear strength and $S^{\mathrm{L}}$ is the longitudinal shear strength. The loop criterion was implemented into the finite-element system MSC. Marc.

\section{RESULTS}

The dependencies of the loop's load capacity $F_{\max }$ on the width $Q$, based on both the experimental and numerical results are presented in Figures 9 and 10. It is obvious that an increase in the width $Q$ did not have a significant influence on the FF loop's load capacity. The load capacity of the TF loops increased with the width $Q$, but only up to the determinate width $(Q=5 \mathrm{~mm})$.

The difference between the experimental and numerical results was minimized in the process of identifying the loop parameter $P_{\mathrm{f}}$. The loop parameter $P_{\mathrm{f}}=0.87$ was identified for the carbon composite and it was $P_{\mathrm{f}}=0.65$ for the glass composite (the value of the loop parameter $P_{\mathrm{f}}$ does not depend on the fastening type). The influence of the loop parameter $P_{\mathrm{m}}$ on the load capacity was not investigated. $P_{\mathrm{m}}$ was assumed to be 0.05 . $^{2}$ 


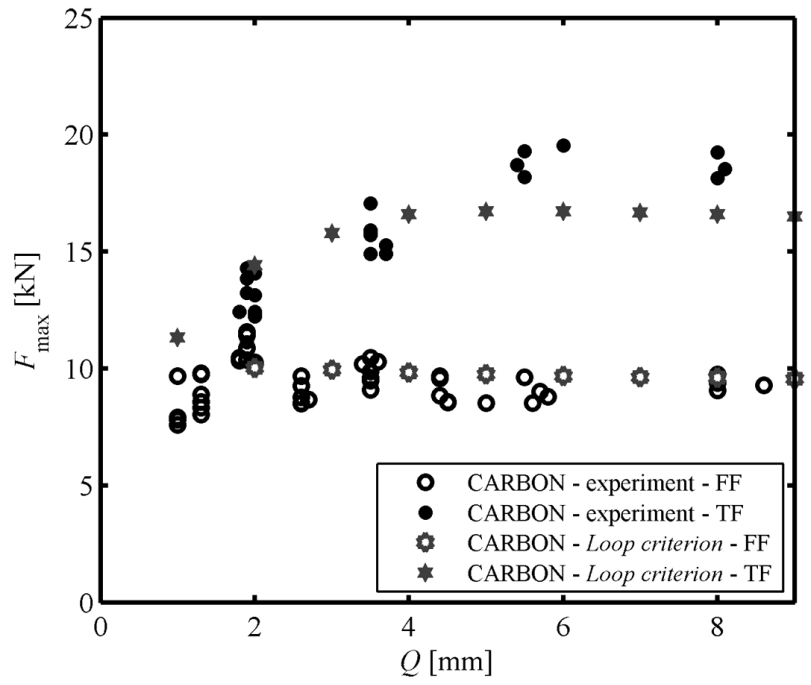

Figure 9: Load capacity of carbon loops

Slika 9: Nosilnost zank z ogljikovimi vlakni

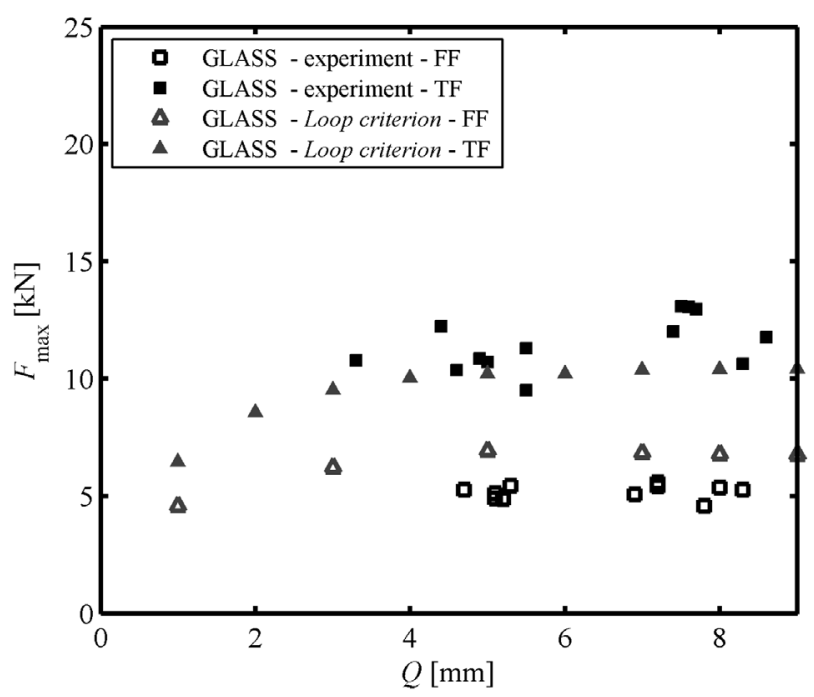

Figure 10: Load capacity of glass loops

Slika 10: Nosilnost zank s steklenimi vlakni

Very good agreement between the experimental and numerical results was achieved in the case of the FF carbon loops (Figure 9). In the case of the TF carbon loops, the difference between the experimental and numerical results was lower than $17 \%$. In the case of the glass composite, sufficient agreement between the experimental and numerical results was achieved for both types of loop fastening (Figure 10). The difference between the experimental and numerical results was lower than $25 \%$.

\section{CONCLUSION}

Experimental dependency of a loop's load capacity on the loop's width was investigated. Carbon loops had a higher load capacity than glass loops. Irrespective of the type of fibres, the TF loops exhibited a higher load capacity than the FF loops. In the case of the FF loops, an increase in the width $Q$ did not have a significant influence on the loop's load capacity. In the case of the TF loops, the influence of the width $Q$ was significant only up to its determinate value.

The loop criterion for determining the loop's load capacity was proposed using the finite-element method. The values of the loop parameter $P_{\mathrm{f}}$ were identified for both analysed materials. With regard to the proposed loop criterion, this parameter does not depend on the type of the loop fastening. The maximum differences between the experimental and numerical results were $17 \%$ for the carbon composite and $25 \%$ for the glass composite.

\section{Acknowledgement}

This publication was supported by the project LO1506 of the Czech Ministry of Education, Youth and Sports.

\section{REFERENCES}

${ }^{1}$ T. Havar, E. Stuible, Design and testing of advanced composite load introduction structure for aircraft high lift devices, ICAF 2009, Bridging the Gap between Theory and Operational Practice, Proceedings of the 25th Symposium of the International Committee on Aeronautical Fatigue, Rotterdam, 2009, 365-374, doi:10.1007/97890-481-2746-7_21

${ }^{2}$ R. Kottner, J. Krystek, R. Zemčík, J. Lomberský, R. Hynek, Strength analysis of carbon fiber-reinforced plastic coupling for tensile and compressive loading transmission, 52 ${ }^{\text {nd }}$ AIAA/ASME/ASCE/AHS/ ASC Structures, Structural Dynamics and Materials, Denver, USA, 2011, doi:10.2514/6.2011-1982

${ }^{3}$ S. T. Pinho, C. G. Dávila, P. P. Camanho, L. Iannucci, P. Robinson, Failure Models and Criteria for FRP under In-Plane or Three-Dimensional Stress States Including Shear Non-Linearity, Research report, NASA/TM-2005-213530, NASA Langley Research Center, 2005

${ }^{4}$ J. Krystek, Damage of composite components under various types of loading, Ph.D. thesis, University of West Bohemia, 2014 (in Czech) 